\title{
建築系複合領域分野の初学者にみる環境要素の実測・演習の導入効果
}

\author{
- 建築環境設計の授業プログラムの開発と実践 その 1 -
}

\section{INSTALLATION EFFECT OF FIELD MEASUREMENT AND PRACTICAL EXERCISE ON ENVIRONMENTAL ELEMENTS UPON ARCHITECTURAL BEGINNERS IN COMPOSITE REGION}

Development and practice of educational program for architectural environmental design: Part 1

\author{
高田眞 人*, 谷口新**, 梅干野 晁 ${ }^{* * *}$
}

\section{Masahito TAKATA, Shin TANIGUCHI and Akira HOYANO}

\begin{abstract}
For enhancing the general level of understanding toward architectural environmental design, it is important not only for ordinal architectural students but also for architectural beginners in composite regions to imagine environmental elements in their design. In this study, as a means of addressing this issue, educational program, in which field measurement on thermal environment and practical exercise on ultraviolet environment was introduce for the discovery of environmental elements in living areas, had been developed and conducted for architectural beginners in composite regions. The results confirmed that the program successfully enhanced students' discovery on environmental elements even if it is very simple. On the other hand, some areas were highlighted for improvement with regards to the content of the lectures and reports in the program.
\end{abstract}

Keywords: Architectural environmental design, Educational program, Composite regions, Architectural beginners, Field measurement and practical exercise

建築環境設計，授業プログラム，複合領域分野，建築系初学者，実測・演習

1. はじめに

地域の気候特性やポテンシャルを活か寸バイオクライマティック デザインの一つとして周辺環境の特性を踏まえた空間設計を目指す 建築環境設計がある、筆者らは, 3D-CAD 対応熱環境シミュレータ ${ }^{1)}$ （以降，シミュレータ）を用いた建築環境設計に関する一連の研究 を行っている ${ }^{2), 3)}$. 大学院生を対象に授業プログラムを開発・実践 した研究では, アンケート調査よりその効果を確認している ${ }^{4), 5) .}$ しかしながら中にはシミュレータが出力した設計案の環境を具体的 にイメージ出来ず，あたかもテレビゲームのように，計算結果を調 整するためだけに壁面緑化等の対策を施す学生もみられた。したが って建築環境設計の教育を進める上で，シミュレーションによる環 境要素の可視化と同時に, 環境要素を学生に理解させる, つまり環 境の形成過程における関係を環境要素ごとに理解させ, 更にシミュ レーション結果と結びつけて納得させる必要性が明らかとなった。 そのためにもまずは環境要素ごとに環境と関係があることを学生に 気づかせる必要がある。

\section{1 環境要素を理解させる教育手法に関する既往研究}

学生に環境要素を理解させる教育手法の開発に関する研究として, 以下のものが挙げられる.
専門教育機関では，大西ら（2011） ${ }^{6)}$ 及び澤田ら（2014） ${ }^{7)}$ に る建築学科の学部生を対象とした授業プログラムの開発と評価が挙 げられる. 大西らによる研究は，一つの建物を構法・環境・構造に ついて包括的に学習することを目的に, 設計製図の授業に構造解析 ソフト, $3 \mathrm{D}-\mathrm{CAD}$, 環境解析ソフトを導入し, 各ソフトの特徴及びソ フト間のデータの連係を活かした演習授業プログラム（授業名：デ ザイン・シミュレーション）を開発・実践し，問題点を明らかにす ることでプログラムを評価している。一方, 澤田らによる研究は, 開発した e-learning システムに BIM・ICT ッールを連携させること で環境情報を見える化し，学生自身による気づき・発見を促す教育 システムを新たに開発した。その上で包括的・統合的な建築設計の アクティブ・ラーニングを実践し，効果を確認している.

小中学校など義務段階の教育機関では, 環境に関する理解を深め るための教育プログラムとして田中ら（2011） ${ }^{8)}$ にる小学生を対 象としたエコスクールの授業プログラムの開発が挙げられる.この 研究は学校施設の物理的な機能の整備だけでなく, その特性に対応 した体系的・継続的な人材育成を目指し，住環境学習プログラムを 小学校教員と共に開発・運用し, 評価すると共にその問題点を精査 している.

\footnotetext{
本論文は既発表文献·1)・22で報告したものに新たな解析結果を加え，加筆・修正し，再構成したものである。

* 熊本大学 助教 - 博士 (工学) Assist. Prof., Kumamoto University, Dr. Eng.

** 大妻女子大学 非常勤講師・博士(工学) Lect., Otsuma Women's University, Dr. Eng.

*** 東京工業大学 名誉教授・工博—Emeritus Prof., Tokyo Institute of Technology, Dr. Eng.
} 


\section{2 建築系複合領域分野への着目}

大西ら (2011） ${ }^{6)}$ や澤田ら (2014） ${ }^{7)}$ は設計者側の視点からの環境 に配慮した建築のデザインを，田中ら $(2011)^{8}{ }^{8}$ は利用者側の視点 から対象者の生活空間の環境要素に関する知識や意識の向上を目的 に，それぞれ授業プログラムを開発したといえる。一方，近年は建 築学分野以外の他分野の科目がカリキュラムにある中で設計や空間 デザインに関連する授業があり, 卒業時に二級建築士の受験資格(学 歴要件）を保証する複合領域分野（以下，建築系複合領域分野）を 有する大学は全国に 60 校存在する注 1$)$ (Table1)。これらの教育機関 では卒業後に必要な実務経験要件（教育機関により必要年数が異な る）に応じて建築に関連する科目（国土交通大臣が指定する建築に 関する指定科目）が設置されている。一方，一級建築士の受験資格 （学歴要件）を保証する建築学分野を有する大学は全国に 110 校あ り, 同一教育機関内に建築学分野と建築系複合領域分野が存在する 大学はさらに 18 校存在することを踏まえると, 建築系複合領域分野 について考察する意義は少なくないと考える. 当該教育機関の学生 に対応した建築環境設計の授業プログラムの開発は，生活空間の環 境要素に対する利用者側の理解や意識の向上，環境への設計者側か らのアプローチの促進, の両面から社会的に重要と考える.

\section{3 本研究の目的}

本報では建築系複合領域分野の学生を対象に，生活空間の環境要 素を定量的に把握させ，環境要素ごとに環境とデザインの因果関係 を理解させる建築環境設計の教育プログラムの開発を目指寸。その 第一段階として簡易実測と演習を通して，生活空間の環境要素に気 づかせることを目的とした初学者用の授業プログラムを開発・実践 し，効果と問題点を考察する。

\section{2. 本授業プログラムの基本構成}

\section{1 授業プログラム全体の区分}

初学者向けの建築設計教育プログラムに関する既往研究として, 2011 年に日本建築学会教育賞を受賞した川北らによる「ステップ・ バイ・ステップ方式を用いた初学者向け建築設計教育プログラムの 実践と教科書の出版」が挙げられる ${ }^{9)}{ }^{10)}$. 上記プログラムは，基本 設計段階で行われる一連のプロセスを 6 段階のステップに区分し， 各ステップで学習目標と作業手順を明示し，クリアさせることで， 設計に必要な基礎知識を全学生に習得できるように配慮している. 小学生を対象としているが田中ら（2011） ${ }^{8)}$ も同様の授業構成とし ている。したがって建築系複合領域分野の初学者に周辺の環境要素 を気づかせる場合も，各ステップで学習目標と作業手順を明示した
上で，クリアさせる授業構成は有効と考える.

なお複合領域分野の学生を対象とするため, 通常の建築系学生を 対象に実施する場合と異なり, 授業導入時に環境と建築デザインに 関する予備知識の付与を目的とした助走期間が必要と判断した.

以上より, 本授業プログラムは, 開始時に知識を補填する助走期 間のステップ (ステップ 1), 取り扱うテーマ毎に授業及び提出され た各種レポートより学生に周辺の環境要素に気づかせるステップ

(ステップ 2〜4), 最終レポート及び理解度の調查による知識の確 認と授業プログラムの評価を目的としたステップ (ステップ 5), に 分割する。なお学生の属性と環境要素への理解度は, 授業初回と最 終回に実施する確認シート（節 4.3 .3 で後述）より把握する.

\section{2 各ステップ内の区分}

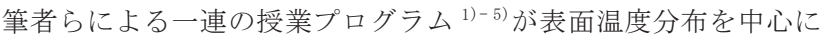
扱っていることを踏まえ, 本授業プログラムでは屋外と屋内の温熱 環境を取り扱うテーマとして, 学生に環境要素への気づきを促す. また授業以外の環境要素に関する予備知識の有無の影響をみること を目的に，平素より日焼けを意識し紫外放射環境に関する知識があ ると予想される女子大学の学生を対象とし, 取り扱うテーマに紫外 放射環境も加える.

テーマ毎に以下に示すセクション構成とする.

$\mathrm{i}$ 講義セクション：生活空間の環境要素に関寸る知識, 特に熱放 射環境に関しては実例と基礎的な物理法則を中心に教える.

ii 簡易実測/演習セクション: 講義で教えた環境要素に関する知 識を簡易実測と演習より確認・把握する.

iii レポートセクション：実測又は演習結果を元に対象地の環境を 分析・報告させることで知識の定着を図る.

建築系複合領域分野の教育機関の多くは複数の分野の内容を同時 に取り扱うため, 設計製図や環境工学など授業時間は通常の建築学 分野よりも更に限られている。したがって助走期間を除いた本授業 プログラムは短期間での知識の習得を前提に, 半期の半分, $7 \sim 8$ 回 （各回 90 分）での環境を目標とする.

以上を踏まえ, Fig. 1 に本授業プログラムの基本構成を示す.

Table1 Number of architectural composite regions

\begin{tabular}{|c|c|c|c|c|c|}
\hline & \multicolumn{3}{|c|}{ 大学数 } & \multirow{2}{*}{\multicolumn{2}{|c|}{ 合計 }} \\
\hline & 国立大 & 公立大 & 私立大 & & \\
\hline 建築学分野のみ & 27 & 10 & 73 & \multicolumn{2}{|c|}{110} \\
\hline 建築系複合領域分野のみ & 11 & 10 & 21 & 42 & \multirow{2}{*}{60} \\
\hline 両方の分野がある & 1 & 2 & $15 \|$ & 18 & \\
\hline
\end{tabular}

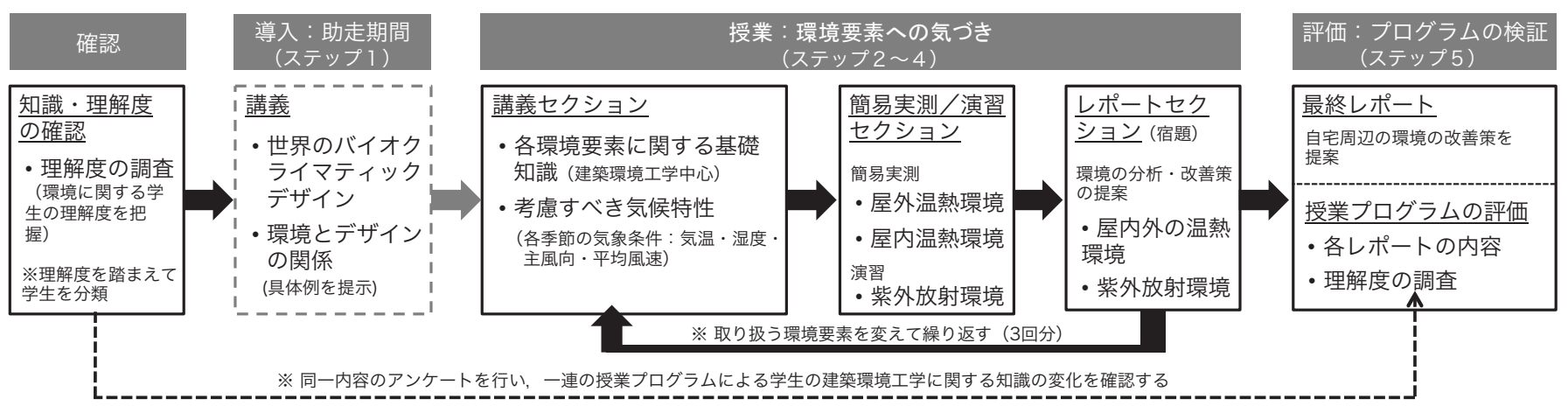

Fig.1 Basic Structure of this Educational Program 


\section{3. 各セクションの内容}

\section{1 講義セクション}

講義は，テーマごとの基礎知識及び実測・演習に必要な情報の習 得を目的とする. 各講義の冒頭に学生に資料を配布する. Fig. 2 に, 講義資料の一例を示す. 資料内容は実例と基礎的な物理法則の解説 を中心に構成され，視覚的な情報を付与するように心掛ける．同時 に記載情報に一部空欄や質問を設け，学生が授業内の情報を書き込 むことで完成させるよう配慮する。

\section{2 簡易実測・演習セクション}

簡易実測及び演習は，学生を複数名の班に分け，班ごとに実施さ せる。これは学生が実測／演習結果を取りまとめ, レポートを作成 する際に，相互に話し合わせることで環境要素への理解を深めさせ ることを意図している.

\section{（1）温熱環境の簡易実測（屋外・屋内）:}

学生に授業内容に興味を持たせる観点から, 実測に先立ち, 使用 する簡易通風温度計 ${ }^{11)}$ と今回筆者が提案する簡易風向風速検知器 を学生に自作させる授業を 1 回設ける.Fig. 3 に, 使用実測機器の 一覧を示寸。これらの計測機器うち，同図内(1)・(2) はアルコール温 度計・牛乳パック・段ボール・竹串・羽毛・ビニール紐・セロファ ンテープ等を材料に，作成方法を明示した紙を参考に，学生が班ご とに作成する。 その際, 指導教員は, 随時, 学生に助言等を行う。

各環境要素の具体的な測定方法は, 以下の通りである。簡易通風 温度計の場合，開口部に団扇で 3 分間風を送り込み，直後のアルコ 一ル温度計の值を測定させる.簡易風向風速検知器の場合, 風向は, 学生が所有するスマートフォンに内蔵されているコンパスを併用し て検知させ， 1 分間の最大值より判断させる。風速は，羽毛につな がれたビニール紐の傾きから「たくさん（水平）・ほどほど（斜め）・ 全く(垂直)」の 3 段階に分類する.なおこの検知器のビニール紐は, 風速 1-2 m/s で斜めに傾く（=「ほどほど」になる）よう事前に長 さ・太さ及び羽毛の大きさが調整されている，放射温度計の場合， 市販されている一般的な放射温度計（測定精度： $\left.\pm 2^{\circ} \mathrm{C}^{\text {注 }} 2\right)$ ）を各グ ループ 1 台ずつ配付し，表面温度を測定させる。なおガラス空の表 面温度に関しては，黒体テープを学生に配布し，事前にガラスに貼 り付け、十分時間が経った上でテープの温度を測定させた。上記手 法ではガラス空の表面温度を測定出来ないが，本研究の目的が材料 に伴う放射温度の違いを学生に把握させることを考慮し, 採用した。 実測地点は，屋内外ともに「温熱環境が良さそう／悪そう」の観 点から学生自身が選定した場所とする.

実測開始時, 対象地の環境要素を計測してメモ寸るための用紙 (以 下，実測メモ用紙）を配付する（Fig. 4)。測定項目は，以下の $6 つ$ である。 (a) 測定時刻, (b) 天候（含：雲の量)，(c) 気温（計測開始 時, 計測終了時), (d) 風向, (f) 風速（たくさん・ほどほど・全く, の 3 段階). なお屋内での風速の計測は, 空調機器からの吹き出し及 び開口部からの気流の流入を意識させるために実施するものである. また屋内の場合のみ, 気温と放射の関係を考察させることを意図し， 各実測地点の周囲 6 面の主要部材の表面温度を測定させる。これら の測定值を指導教員が用意した Exce1 シートに代入させ実測地点の 平均放射温度（MRT）を簡易的に算出させる.

一方，学生による実測結果の正誤の検証を目的に，指導教員は実 測機器（Fig. 3 内 (3), (4), (5) ) を使用し, 別途, 環境要素（外気温・
室温・相対湿度・風向・風速）を実測する.

\section{(2) 紫外放射環境の演習}

学生が選定した全実測地点（高さ $1.2 \mathrm{~m}$ ) における上空を等距離 射影の魚眼レンズを装着したデジタルカメラを用いて撮影する。こ

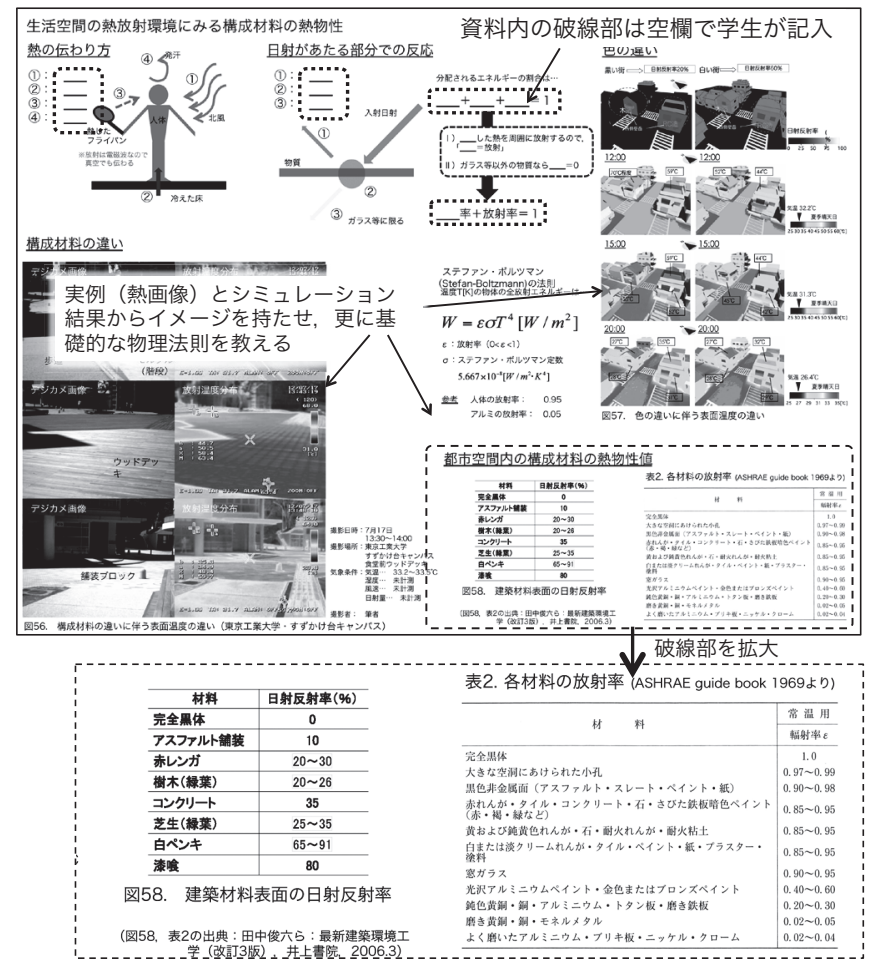

Fig.2 Handout used in the lecture section (example)

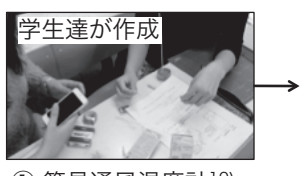

(1) 簡易通風温度計 10$)$ 側面の通風口に向けて団扇を
3分間扇ぎ, 気温を測定

(2) 簡易風向風速測定器 コンパスで方位を確認
1分間の平均值を採用
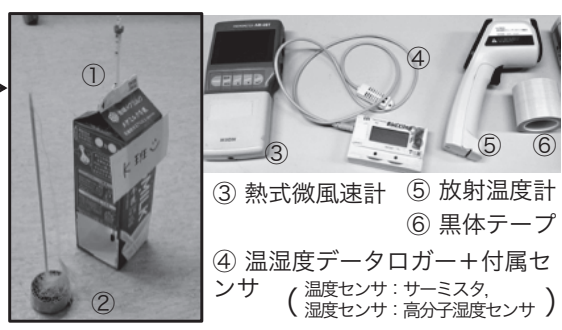

(3) 熱式微風速計 (5) 放射温度計 (6) 黒体テープ

(4) 温湿度データロガー+付属セ

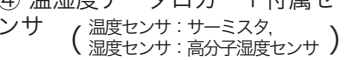

Fig.3 Hardware used in the field measurement

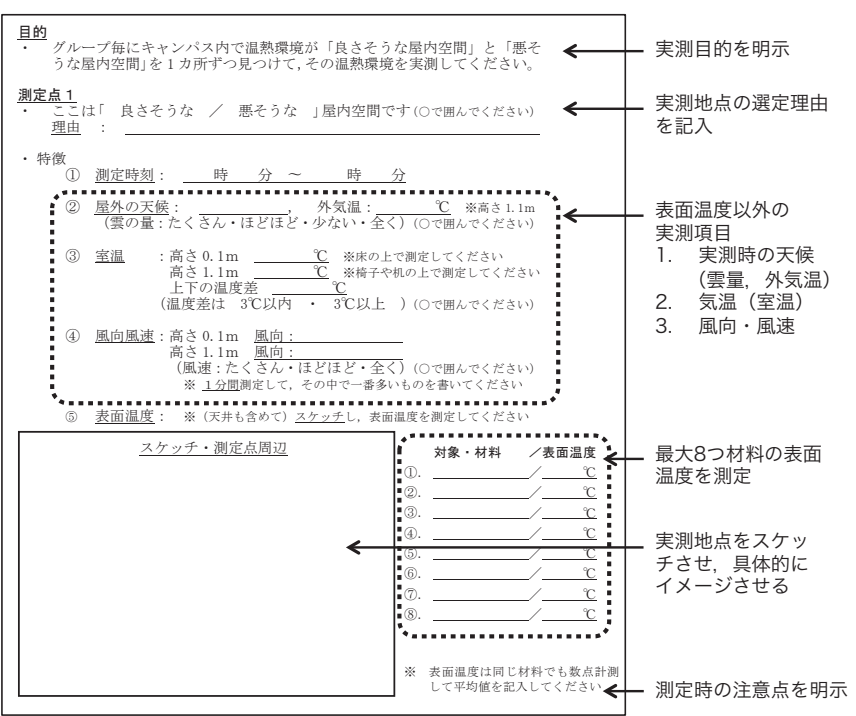

Fig.4 Memo paper used in the field measurement 
の写真（以下，魚眼写真）のデジタルデータをランダムに印刷した A4 版用紙（以下，作業用紙）を全学生に配付し, 班ごとに作業させ る。その際，学生間で対象地が重複しない上う考慮する。続いて, 作業用紙上に OHP に印刷した川西 ${ }^{12)}$ による「紫外線日除けチャート」 を使って指導教員の指定する特定日における紫外放射環境を，同じ く川西の提案する建築的太陽防御指数（以降, ASPF）を算出させる ことで評価させる.Fig. 5 に，演習の概要を示す．評価対象となる 特定日は太陽高度と年平均気温から判断し, 夏至と盆とする。学生 はこれら特定日の 10 時から 14 時における時刻を自由に選択し，そ の時刻における太陽高度・太陽方位から対象地の紫外放射環境を評 価する. 計 6 回作業を行わせ，季節と時刻の変化に伴う紫外放射環 境の違いを把握させる.

\section{3 レポートセクション}

レポートは，実測及び演習結果を元に対象地の環境を分析・報告 させることでこれまで意識していなかった環境要素に気づかせると ともに，得られた知識の定着を図ることを目的とする.

温熱環境に関しては, 実測項目の取りまとめに加え, 以下の作業 を追加する（a）実測地点の配置図（方位とスケールを入れる），(b) 写真，(c) スケッチ（材料の違いを認識させるため彩色させる), (d) 良さそう／悪そうと思った理由・実測地点の選定理由（e) 実測への 感想．屋内の実測結果に関するレポートのみ，上記項目に加え，対 象地の平均放射温度 (MRT) を算出させ, 気温との違いを記述させる.

紫外放射環境に関しては，演習での対象地の紫外放射環境の評価 結果，及び先の温熱環境の簡易実測結果も踏まえ，対象地の環境の 改善策を提案させる.これは対象地の現状を温熱環境・紫外放射環 境，双方の知識を踏まえて分析させることを意図している．温熱環 境のレポートと同様，実測項目の取りまとめに加え，以下の作業も 義務づける. (a) 対象地の配置図 (方位とスケールも記載), (b) 写真, (c) 彩色スケッチ, (d) 対象地点の選定理由 (e) 演習への感想.

\section{4 最終レポート}

最終レポートでは, 一連の授業より得られた知識を踏まえ, 温熱 環境と紫外放射環境の視点から学生自身の住宅及びその周辺環境の 改善策を, 最終授業の授業時間内に提案させる. Fig. 6 に, 最終レ ポートの作成時に学生に配付した記入用紙を示寸。提案に際して, 以下の作業を義務づけた。（a）周辺を含む自身の住宅の平面図（方 位・スケール明記)，（b）ある地点から見たパース，(c) 問題点， (d) 導入した対策.

\section{4. 本授業プログラムの実践と考察}

本授業プログラムは，二級建築士の資格の取得を教育目標の一つ に掲げている教育機関（私立女子大学）の建築系複合領域分野（社 会情報学部環境情報学専攻）の学部 3 年生 70 名（授業開始時）を対 象とする通常講義の授業「環境デザイン論」（半期・全 15 回 : 各回 90 分）で実施した. Table2 に, 本授業プログラムの各回の概要を示 す、ガイダンスやまとめ回などを除き, 通常授業 8 回に助走期間 4 回の正味 12 回で実施した。期間は 2013 年 9-12 月である.

\section{1 指導教員と学生の属性}

指導教員は授業の主担当 1 名, 補助 1 名の計 2 名で行った。主担 当（高田）は建築環境工学と建築環境設計を専門としている．補助 （谷口）は建築計画と建築教育を専門としている．両名とも建築学

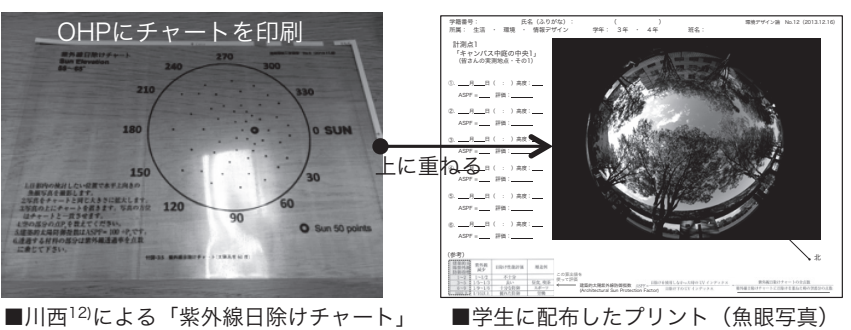

Fig.5 Way to evaluate ultraviolet radiation

Table2 Composition of the educational program

\begin{tabular}{|c|c|c|c|}
\hline & 内容 & ねらい & 授業形式 \\
\hline & $\begin{array}{l}\text { 地域の気候特性と環境 } \\
\text { に関する講義・1 }\end{array}$ & $\begin{array}{l}\text { 世界の都市と建物にみる地域の気候特性とデ } \\
\text { ザイン（主に空間構成）との関係を学ぶ }\end{array}$ & $\begin{array}{l}\text { 講義 } \\
\text { (90分) }\end{array}$ \\
\hline 2) & $\begin{array}{l}\text { 地域の気候特性と環境 } \\
\text { に関する講義・2 }\end{array}$ & $\begin{array}{l}\text { 環境以外にも, 地割・居住者の生活行動等が } \\
\text { デザインに影響を及ぼすことを学ぶ }\end{array}$ & $\begin{array}{l}\text { 講義 } \\
\text { (90分) }\end{array}$ \\
\hline 3) & $\begin{array}{l}\text { 地域の気候特性と環境 } \\
\text { に関する講義・3 }\end{array}$ & \begin{tabular}{|l|} 
前 2 回の講義で得た知識を元に江戸町人地の \\
温熱環境を具体例に再度確認する
\end{tabular} & $\begin{array}{l}\text { 講義 } \\
\text { (90分) }\end{array}$ \\
\hline & $\begin{array}{l}\text { 地域の気候特性と環境 } \\
\text { に関する講義・4 }\end{array}$ & \begin{tabular}{|l|} 
日本の伝統的な暮らし方が夏季の暑さに対応 \\
していたことを示し, 環境要素を意識させる
\end{tabular} & $\begin{array}{l}\text { 講義 } \\
\text { (90分) }\end{array}$ \\
\hline & $\begin{array}{l}\text { 簡易計測機器の作成 } \\
(\text { 気温, 風向 } \cdot \text { 風速 })\end{array}$ & $\begin{array}{l}\text { 2週間後の実測に向け, 班ごとに簡易実測機 } \\
\text { 器を作成させ, 興味を持たせる }\end{array}$ & $\begin{array}{c}\text { 演習 } \\
\text { (90分) }\end{array}$ \\
\hline & $\begin{array}{l}\text { 屋外の温熱環境に関す } \\
\text { る講義 }\end{array}$ & $\begin{array}{l}\text { 材料に伴う表面温度の違い, 温熱環境に関す } \\
\text { る基礎知識（熱伝導・放射・対流等）を学ぶ }\end{array}$ & $\begin{array}{c}\text { 講義 } \\
\text { (90分) }\end{array}$ \\
\hline & $\begin{array}{l}\text { 周辺環境の簡易実測 } 1 \\
\text { (屋外の温熱環境) }\end{array}$ & $\begin{array}{l}\mid \text { 環境要素（気温・風速・風向・表面温度）の } \\
\text { 簡易実測より, 屋外の温熱環境を実させ感させる }\end{array}$ & $\begin{array}{l}\text { 演習 } \\
\text { (90分) }\end{array}$ \\
\hline & $\begin{array}{l}\text { 屋内の温熱環境に関す } \\
\text { る講義 }\end{array}$ & $\begin{array}{l}\text { 先の屋外の温熱環境に関する知識に加えて窓 } \\
\text { 面や壁面での熱の伝導・放射·対流を学ぶ }\end{array}$ & $\begin{array}{l}\text { 講義 } \\
\text { (90分) }\end{array}$ \\
\hline & $\begin{array}{l}\text { 周辺環境の簡易実測 } 2 \\
\text { （屋内の温熱環境） }\end{array}$ & $\begin{array}{l}\text { 環境要素（気温・風速・風向・表面温度）の } \\
\text { 簡易実測と平均放射温度(MRT)の算出より, } \\
\text { 屋内の温熱環境を実感させる }\end{array}$ & $\begin{array}{c}\text { 演習 } \\
\text { (90分) }\end{array}$ \\
\hline & $\begin{array}{l}\text { 紫外放射環境に関する } \\
\text { 講義 }\end{array}$ & $\begin{array}{l}\text { 紫外線の特性, 都市における紫外線対策, 及 } \\
\text { び樹木の効果を学ぶ }\end{array}$ & $\begin{array}{l}\text { 講義 } \\
\text { (90分) }\end{array}$ \\
\hline & $\begin{array}{l}\text { 演習による周辺環境の } \\
\text { 把握（紫外放射環境） }\end{array}$ & \begin{tabular}{|l} 
「紫外線日除けチャート」を使用して屋外で \\
の紫外線の影響を実感する
\end{tabular} & $\begin{array}{c}\text { 演習 } \\
\text { (90分) }\end{array}$ \\
\hline & $\begin{array}{l}\text { 最終レポート（自宅周 } \\
\text { 辺に快適な環境を実現 } \\
\text { する） }\end{array}$ & $\begin{array}{l}\text { 一連の授業より得られた知識をもとに, 学生 } \\
\text { の自宅周辺を対象に, 環境の観点から再デザ } \\
\text { インさせ, 知識の定着を図る }\end{array}$ & $\begin{array}{c}\text { 演習 } \\
\text { (90分) }\end{array}$ \\
\hline
\end{tabular}

Table3 Attribution of participating students

\begin{tabular}{|c|c|c|c|c|c|c|c|c|c|}
\hline \multicolumn{5}{|c|}{ 学生 } & \multicolumn{3}{|c|}{ 設計製図の授業 } & \multicolumn{2}{|c|}{ 方位の明記 } \\
\hline 総数 & 所属 & 分野 & 体制 & 教育目標 & 履修済 & 再履修 & 未履修 & 出来た & 出来ない \\
\hline 70名 & $\begin{array}{l}\text { 社会情報学部 } \\
\text { 環境情報学専攻 }\end{array}$ & \begin{tabular}{|l} 
建築系複 \\
合領域 1 \\
\end{tabular} & $\begin{array}{l}\text { 女子 } \\
\text { 大学 }\end{array}$ & \begin{tabular}{|l} 
二級建築 \\
士*2
\end{tabular} & \begin{tabular}{|l|}
6 名 \\
$(9 \%)$ \\
\end{tabular} & $\begin{array}{l}\begin{array}{l}3 \text { 名 } \\
(4 \%)\end{array} \\
\end{array}$ & \begin{tabular}{|l}
$\begin{array}{l}61 \text { 名 } \\
(87 \%)\end{array}$ \\
\end{tabular} & \begin{tabular}{|l}
35 名 \\
$(50 \%)$
\end{tabular} & \begin{tabular}{|l|}
35 名 \\
$(50 \%)$
\end{tabular} \\
\hline
\end{tabular}

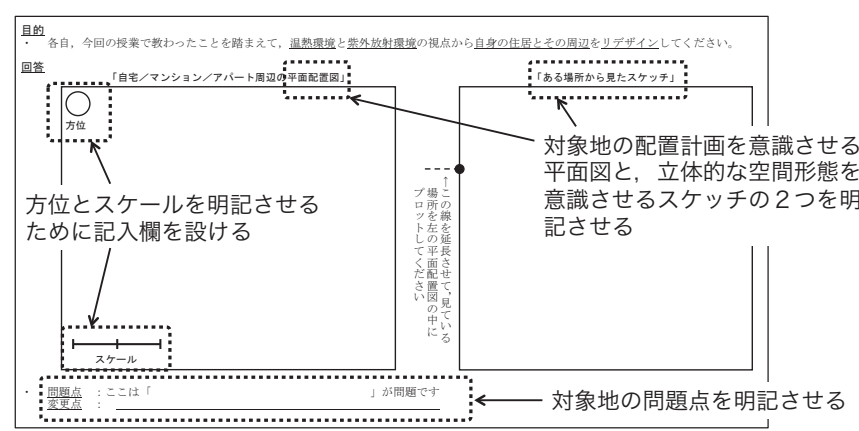

Fig.6 Memo paper used in the final report

科出身であり, 設計製図の授業を経験している. 講義は主担当が行 い, 簡易実測及び演習は主担当と補助の両名が実測及び計測機器の 操作方法に関する助言等を行った.

初回授業冒頭に生活空間の温熱環境の理解度に関する調査を行っ た。また自身が選択した敷地の平面図と敷地配置図を描かせ，図の 精度と方位・スケールの有無より設計製図の経験及び空間把握能力 
を確認した. Table3に, 理解度の調査より明らかとなった受講学生 の属性を示す. 結果, $87 \%$ (61名)の学生が設計製図の経験がなく, 方位を明記できた学生は全体の半数であることを把握した。この点 を踏まえ，本授業プログラムでは設計製図の経験者及び方位を明記 できていた学生をリーダーに据え, 各 6-8 名, 計 11 の班に分け, 実 測及び演習にあたらせることにした。

\section{2 簡易実測及び演習の概要}

温熱環境の簡易実測は, 屋外に関しては 2013 年 11 月 11 日（晴天 日） $13: 30 〜 14: 30$ に, 屋内に関しては同年 12 月 2 日（晴天日） $13: 30$ 〜 14: 30 に実施した。高さ $1.5 \mathrm{~m}$ における当日の気象は, 11 月 11 日 は外気温 $16.5^{\circ} \mathrm{C}$, 相対湿度 : $68-70 \%$, 風速 : $1-3 \mathrm{~m} / \mathrm{s}$ であった. 12 月 2 日は外気温 $13.5^{\circ} \mathrm{C}$, 相対湿度 : 60-65\%, 風速 : $2-3 \mathrm{~m} / \mathrm{s}$ であっ た. 実測地点は, 屋外が 11 地点, 屋内が 13 地点であり, すべて学 生自身が選定した. Fig. 7 に, 実測地点の一覧を示す.

両実測とも，実測開始時に実測メモ用紙を配付し，教員と補助員 が学生に計測機器の操作方法に関する助言等を行った。また全学生 が必ず 1 回以上は機器を使って環境要素を測定するよう指示した.

一方, 紫外放射環境の演習は, 2013 年 12 月 16 日に講義室で実施 した。演習自体は個人作業であるが，学生を簡易実測と同一の班に 分け, 学生同士が話し合いながら作業を進めるよう配慮した。

実測及び演習ともに, 実施 1 週間後にレポートを提出させた.

\section{3 本授業プログラムの効果}

本節では授業プログラムの効果を, 学生による環境要素の把握状 況及び授業後のレポート及び確認シートの結果から確認する。なお 本報における「環境要素の把握」とは, 学生が指導教員および資料 内の指示の通りに環境要素を計測し，その後も作業できているか， と定める.

レポートの提出状況は，簡易実測が屋外・屋内ともに $100 \%$ ，紫 外放射環境の演習が 99\%である.最終レポートの提出状況は $84 \%$ (58 名）である。確認シートの回答率は $83 \%$ である.

\section{3.1 簡易実測及び演習による環境要素の把握}

簡易実測の結果は, 屋内外ともに, (a) 対象となる環境要素を全て 計測出来ている，(b) 対象地のスケッチと配置図が記載されている, (c) 計測した環境要素から多少なりとも対象地の環境について考察 できている,の 3 点を基準に評価し，これら全てを満たすレポート を「十分」と判定する. 紫外放射の演習の結果は, (a) 対象地の ASPF を算出している，(b) 対象地の配置図が記載されている，(c) 提案の スケッチがある, (d) 先の温熱環境の実測結果を多少なりとも踏まえ て対象地を分析できている, の 4 点を基準に評価し, これら全てを 満たすレポートを「十分」と判定する。

\section{（1） 屋外の温熱環境の把握}

Fig. 8 (a)に, 屋外の簡易実測に関するレポートの評価結果を示す. 結果，48 名（69\%）の学生が温熱環境（外気温・表面温度・風向・ 風速）の測定に成功し，34名（49\%）が「十分」と判定された。し たがって, 約半数の学生が実測手順に沿うことで対象空間の温熱環 境を把握できたことが分かる。

一方, 配置図内のスケールに関しては, 事前の周知にもかかわら ず 17 名（24\%）しか記載されておらず，レポート提出時に多くの学 生から「スケールというものが分からなかった」という声が聞かれ た. 教員からの説明を元に 21 名 $(30 \%)$ の学生が加筆したが， 32
名 $(46 \%)$ の学生が記入に失敗していた. したがって建築系複合領 域分野の初学者を対象とする場合, スケールや方位の記入のように 設計製図の授業を履修する建築学科の学生にとっては基礎的な事項 に関してもあえて教える必要があることも明らかとなった。

\section{（2）屋内の温熱環境の把握}

Fig. 8(b)に, 屋内の簡易実測に関するレポートの評価結果を示す. 事前に屋外の簡易実測を経験しているため，8 名多い56 名（83\%） が全ての環境要素の測定に成功しており, 学生が環境要素の測定方

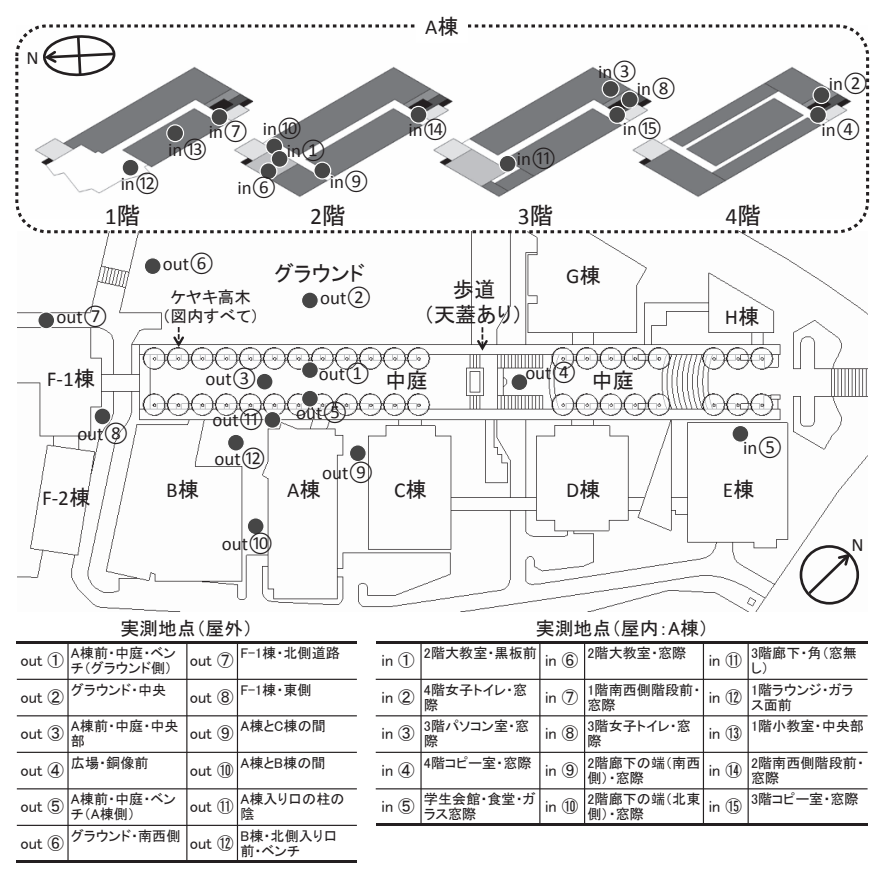

Fig.7 Measurement points by students (Outside \& Inside)

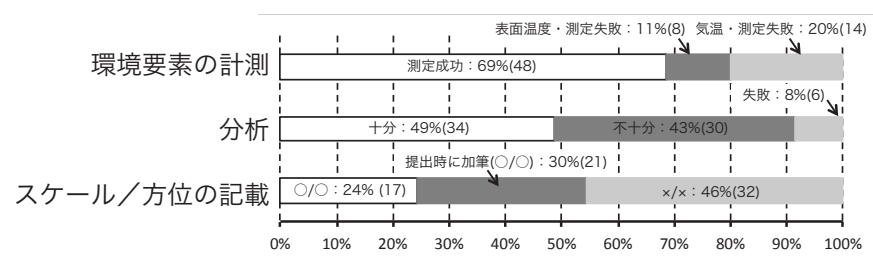

(a) 屋外の温熱環境の実測

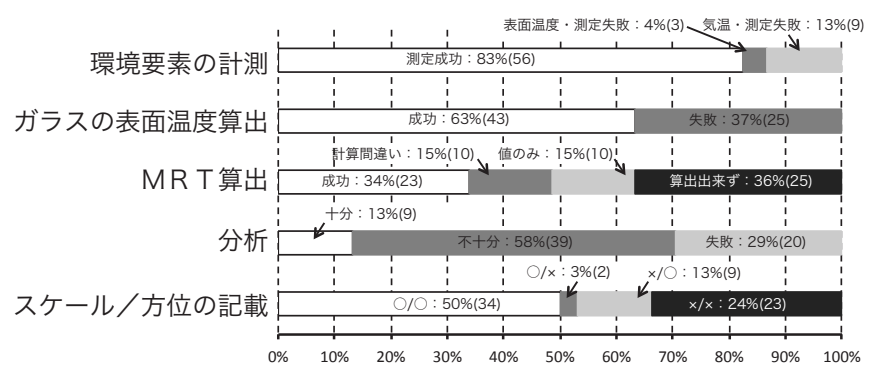

(b) 屋内の温熱環境の実測

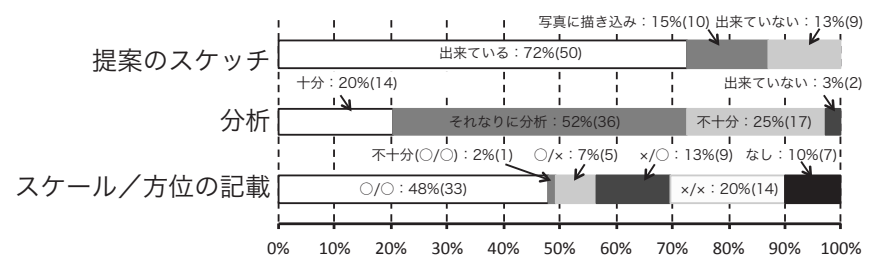

(c) 紫外放射環境の演習

Fig.8 Content of the Students' reports 
法に習熟したと考えられる。しかし屋内の実測にのみ導入した実測 地点における平均放射温度（MRT）の算出結果に関しては，34\%(23 名）の学生しか算出に成功していない，失敗は全て配付した Excel ファイル内の所定欄への入力間違いに起因するものであった. 結果, 屋外実測と比べて 25 名少ない 9 名 $(13 \%)$ のみ「分」と判定され た．この様な入力間違いを防ぐため, 導出プロセスでのケアレスミ ス防止の必要性が明らかとなった。

\section{(3) 対象地の紫外放射環境の把握}

Fig. 8 (c)に，紫外放射環境に関するレポートの評価結果を示す. 結果，紫外放射環境と温熱環境の両方を「十分」に分析した学生及 び紫外放射環境のみを分析した「それなりに分析」した計 50 名 (72\%) の学生が解析結果を踏まえて分析したことになる. そして同数の学 生が対策を提案している。しかしながら，屋内外の実測メモ用紙が 手元にあったにも関わらず，紫外放射環境と温熱環境の両方を「十 分」に分析した学生は先の 50 名中 14 名 (20\%) のみであった。こ のことから，多くの学生が簡易実測の結果を参照せずにレポートを 作成した可能性がみてとれ，導出プロセスの見直しが必要であるこ とが明らかとなった。

\section{3.2 レポート内の感想にみる本授業の効果 \\ （1）温熱環境に関する感想}

Table4に，感想の集計結果を示す. 51 名（73\%）の学生が計測し た環境要素に言及し，そのうちの 11 名（16\%）は「日陰と日向で表 面温度に差があることに驚いた」，「日陰と日向で気温は大きく違わ ない事に驚いた」,「材料の違いで表面温度が違うことを実感した」 等，気温や表面温度を知ることに伴う驚きを記述していた。また実 測を実施した時期が 11 月下旬であったため, 空ガラス以外には屋内 の主要部材の表面温度に明確な差がみられないこと, MRT が室温よ りも低くなること，に驚いたという感想も見られた。したがって, 簡易的な手法と測定内容の簡易実測によって学生に環境要素を把握 させることが可能であることが明らかとなった。

また牛乳パックやビニール紐や羽毛といった身近な材料を使った 実測機器の作成，及びそれらで環境要素が簡単に測定可能であるこ とへの驚きの感想も少数（7 名）みられた。したがって簡易な実測 機器であっても自身で作成させることで, 建築系複合領域分野の初 学者にも授業内容に興味を持たせることができることが確認された。

しかしながら，気温や表面温度について誤って計測した測定值を 正しい值と誤認する学生が 9 名（13\%）もおり，実測時の教員によ る適切な補助の必要性も確認された。節 4.3 .1 及び節 4.3 .2 におい て, 計測值に基づき対象地の環境を分析できた学生は屋外で $49 \%$, 屋内で 13\%であることを考慮すると, 実測した空間の環境を学生に 分析させる上で，より具体的に誘導する工夫が必要と考える.

\section{（2）紫外放射環境に関する感想}

Table5 に, 感想の集計結果を示す. 結果, 43 名 (62\%)の学生が, 樹木の下で紫外放射環境が大きく改善することに驚いていた．本授 業プログラムを実施した大学キャンパスには街路樹が多く, 屋外の 実測地点にも街路樹の下の空間が選定されていた（Fig.6）。演習で は，これらの実測地点と建物に囲まれた空間やグラウンドなど他の 実測地点が必ず含まれていたため，紫外放射環境の評価結果を相互 に比較することが可能であった。これにより樹木の効果を具体的に 理解できたと考える.
15 名（22\%）の学生がこれまでの日常生活で意識していなかった 環境要素を今回の授業で意識するようになったと言及している。こ れは 2 回目のレポートの 11 名 $(16 \%)$ より数名多く（Table4），一 連の授業を通して少なからず環境要素に気づき，それを意識するよ うになった可能性が考えられる。また 9 名（13\%）の学生から実測 と演習を楽しんだという感想が，8 名（12\%）の学生から簡易的に 紫外放射環境を評価出来ることに驚いたという感想が得られ, 両方 に言及した学生を合わせると温熱環境の時よりも多い 21 名（30\%） の学生が授業に対して肯定的な感想を記述しており, 2 回目より 3 回目と学生が段階的に授業内容に集中していることが分かる.

\section{3.3 確認シートにみる本授業プログラムの効果}

本授業プログラムで取り扱う生活空間の環境要素の理解度を確認 シートより把握する. シートは初回授業の開始時と最終授業の最後 に同一内容で配付し, 回答の変化より本授業プログラムを通して知 識が身についたか, その効果を把握した. Fig. 9 とTable6に, 確認 シートの内容を示す.

Table7 に，アンケート調査の結果を示す。まず紫外放射環境に関 しては，温熱環境と異なり正答率が $31 \%$ から $50 \%$ に上昇している. 3 回目の紫外放射環境のレポート内の自由形式の感想においても 43 名 $(62 \%)$ の学生が紫外放射環境に言及しており（Table5）, 紫外放

Table4 References to environmental elements in the $2^{\text {nd }}$ report

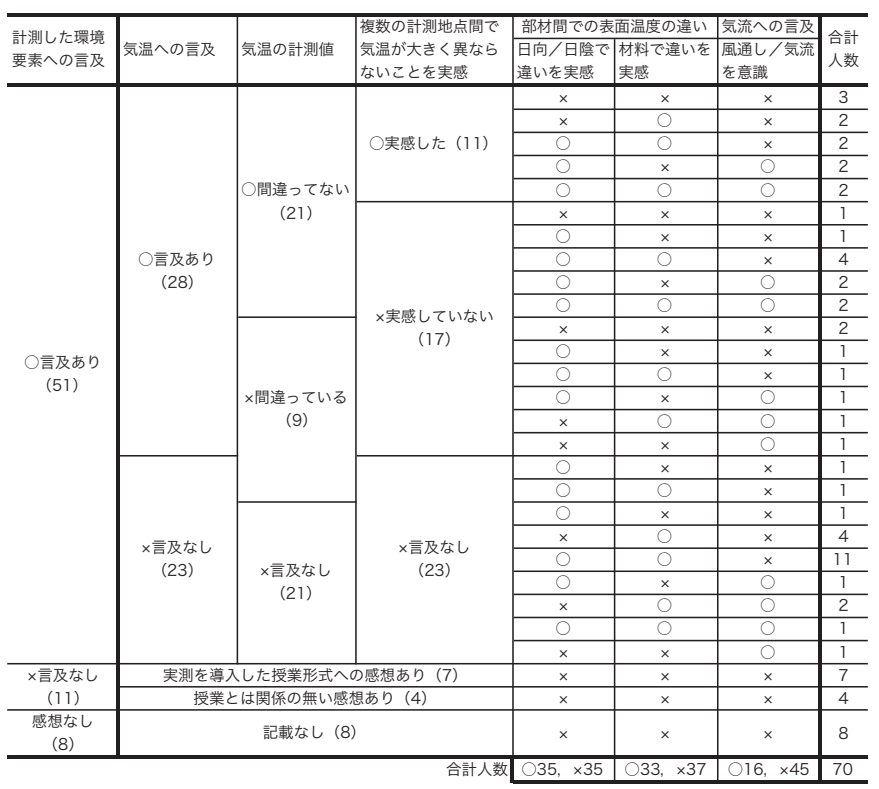

Table5 Debrief reports in the $3^{\text {rd }}$ report (about Environment)

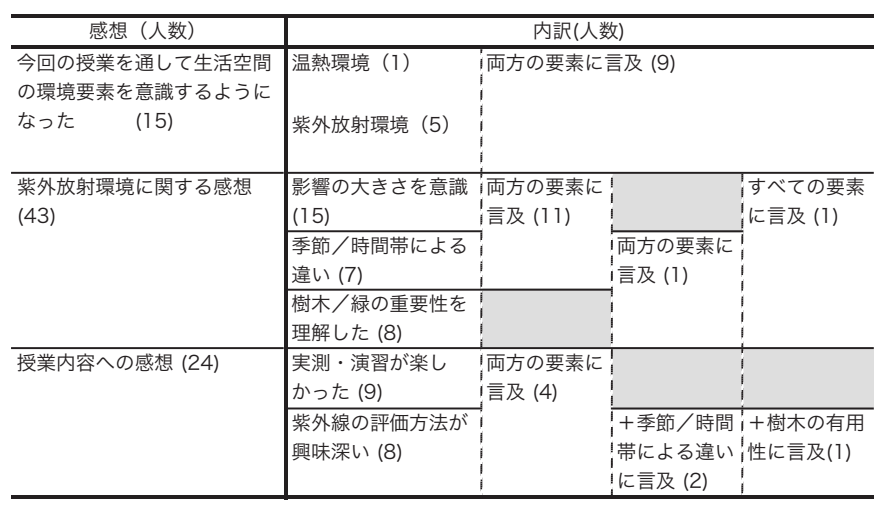


射環境のみの正答率の高さ, 及び学生が女性のみである点を考慮す ると, 当初の狙い通り日頃より日焼けを意識した女子大学の学生特 有の結果の可能性が考えられる.

温熱環境に関しては, 夏季日中の住宅地の温熱環境の正答率が $63 \%$ 上昇し $79 \%$ となっている. しなしながら，それ以外の日中と夜 間の公園，ウッドデッキ，夜間の住宅地に関しては，演習後に正答 率が低下している.したがって, 大気放射と部材の熱容量に関して, 学生による理解不足がみてとれる。この点に関しては簡易実測時に 選定する実測地点や測定する部材の構成材料を工夫することによっ て, 改善が期待できると考える.また一部の選択肢が樹木・空間形 態・構成材料の影響が複合化したものであったため, 各要素の影響 を分割して判断できる学生が少なかったことも正答率の低下に影響 したと考えられる.

\section{4 対象地の選定理由・問題点・対策にみる環境要素への気づき}

続いて，本授業プログラムを通して受講生がそれまで意識してい なかった環境要素への気づきについて確認する，本報における「気 づき」は，レポート・最終レポート・授業後アンケート内に挙げら れている環境要素に関する記述をパラメータに，意識的にせよ無意 識的にせよ, 受講生がそれらに言及しているかどうかより把握する. その際，学生が，(1)何を問題としたか，(2)どの様に対応したか，(3) それがどの程度登場しているのか，に着目する。

具体的には, まず対象地の選定理由より, 環境要素について学生 が何を問題としているのかを把握する。その上で，各レポート内の 感想, 最終レポートでの対象地の問題点とその対策より, 学生によ

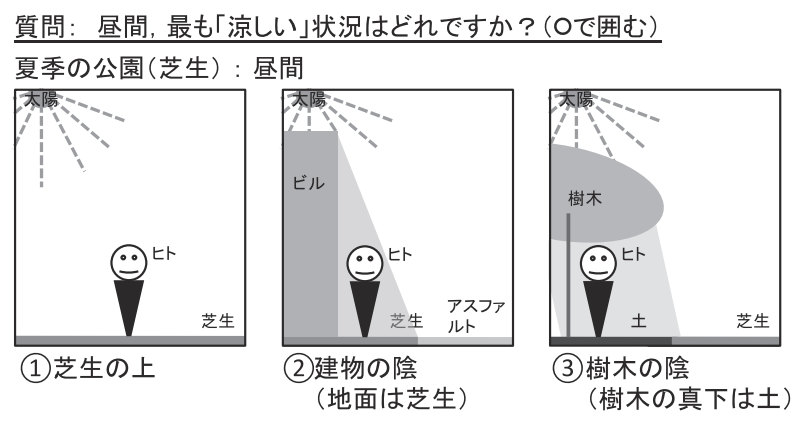

Fig.9 Pictures in the before-and-after quiz (example)

Table6 Items in the before-and-after quiz

\begin{tabular}{|c|c|c|}
\hline 夏季の & 昼間：最も「涼しい」状況はどれですか？（○で囲む） & \\
\hline \multirow{3}{*}{ 公園: } & (2.建物の陰（地面は芝生） & (3).尌木の陰（樹木の真下は土） \\
\hline & \multicolumn{2}{|l|}{ 夜間：最も「涼しい」状況はどれですか？（○で团む） } \\
\hline & (2.建物の陰（地面に & (3.樹木の陰（樹木の真下は土） \\
\hline 夏季の & \multicolumn{2}{|l|}{ 㡺間：最も「涼しい」状況はどれですか？（○で囲む） } \\
\hline ウッド & (2).建物の陰（ガラス面に隣接）＋風 & (3)、樹木の陰十風（樹 \\
\hline \multirow[t]{2}{*}{ デッキ } & \multicolumn{2}{|l|}{ 夜間：最も「涼しい」 状況はどれですか？（○で囲む） } \\
\hline & (2.建物の陰（ガラス面に隣接）＋風 & (3).樹木の陰十風（街木 \\
\hline 夏季の & \multicolumn{2}{|l|}{ 㡺間：最も「涼しい」 状況はどれですか？（○で囲む） } \\
\hline \multirow[t]{2}{*}{ 住宅地 } & (1).住宅地の道（地面アスファルト） & 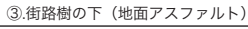 \\
\hline & $\begin{array}{l}\text { 夜間：最も「暑い」状況はどれですか？（○で囲む） } \\
\text { (1).住宅地の道 (地面アファルト) } \\
\text { (2).ビルの陰（地面アスファルトト) }\end{array}$ & (3)街路樹の下（地面アスファルト） \\
\hline 冬季の & \multicolumn{2}{|l|}{ 夜間：寝る際，最も「䁔かい」状況はどれですか？（○で囲む） } \\
\hline 自室 & (2. 布団ナマット (直敷ぎ空隣接) & (3. 布団+ベッド (空隣接) \\
\hline 夏季の & \multicolumn{2}{|l|}{ 昼間：最も「日焼けしない」のは,どの状況でしょう？（○で囲む） } \\
\hline 銀座 & (1).パラソルの下 (地面アスファルト) （2.ビル（ガラス・アルミ面）の陰 & (3)街路樹の下（地面アスフ \\
\hline
\end{tabular}

Table7 Percentage of correct answer in the quiz

\begin{tabular}{|c|c|c|c|c|c|c|c|c|c|}
\hline & \multicolumn{2}{|c|}{ 夏季の公園 } & \multicolumn{2}{|c|}{ 夏季のウッドデッキ } & \multicolumn{2}{|c|}{ 夏季の住宅地 } & \multirow{2}{*}{\begin{tabular}{|c|} 
冬季の自室 \\
夜間 \\
\end{tabular}} & \multirow{2}{*}{$\begin{array}{c}\text { 夏季の銀座 } \\
\text { 昼間 }\end{array}$} \\
\hline & & 昼間 & $\begin{array}{l}\text { 夜間 } \\
\end{array}$ & 昼間 & $\begin{array}{l}\text { 夜間 } \\
\end{array}$ & 昼間 & \begin{tabular}{l|} 
夜間 \\
\end{tabular} & & \\
\hline 正 & 受講前 & $94 \%$ & $26 \%$ & $24 \%$ & $27 \%$ & $63 \%$ & $66 \%$ & $54 \%$ & $31 \%$ \\
\hline 率 & 受講後 & $83 \%$ & $19 \%$ & $24 \%$ & $21 \%$ & 79\% & $62 \%$ & $60 \%$ & $50 \%$ \\
\hline \multicolumn{2}{|c|}{$\begin{array}{l}\text { 理解度を確認 } \\
\text { する事項 }\end{array}$} & \multicolumn{2}{|c|}{ 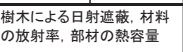 } & \multicolumn{2}{|c|}{ 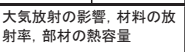 } & \multicolumn{2}{|c|}{ 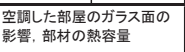 } & 勢妘導の影 & $\begin{array}{l}\text { 訾外放射の } \\
\text { 的暨 }\end{array}$ \\
\hline
\end{tabular}

Table8 Reason for selecting the measuring point (Good \& Bad) (a). 屋外の実測地点

\begin{tabular}{|c|c|c|c|c|}
\hline \multirow{2}{*}{$\begin{array}{l}\text { 班名 } \\
\text { (人数) }\end{array}$} & \multicolumn{2}{|r|}{ 良いと思った場所 } & \multicolumn{2}{|r|}{ 悪いと思った場所 } \\
\hline & 地点 & 選定理由 & 地点 & 選定理由 \\
\hline A (7名) & \begin{tabular}{|l} 
out \\
(1)
\end{tabular} & 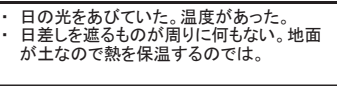 & $\begin{array}{l}\text { out } \\
\text { (5) }\end{array}$ & 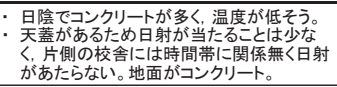 \\
\hline B (7名) & $\begin{array}{l}\text { out } \\
\text { (1) }\end{array}$ & 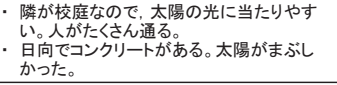 & $\begin{array}{l}\text { out } \\
\text { (6) }\end{array}$ & 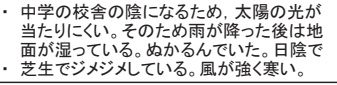 \\
\hline C (7名) & \begin{tabular}{|l} 
out \\
(2)
\end{tabular} & 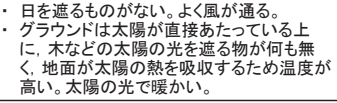 & $\begin{array}{l}\text { out } \\
\text { (5) }\end{array}$ & 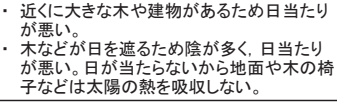 \\
\hline D (7名) & $\begin{array}{l}\text { out } \\
\text { (2) }\end{array}$ & 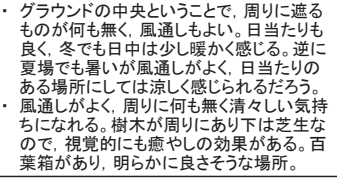 & $\begin{array}{l}\text { out } \\
\text { (7) }\end{array}$ & 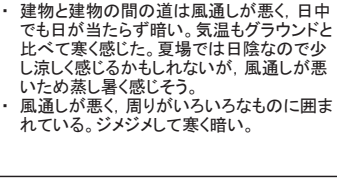 \\
\hline E (7名) & \begin{tabular}{|l} 
out \\
(3)
\end{tabular} & 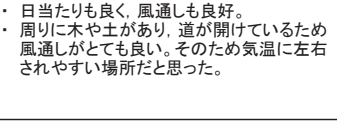 & $\begin{array}{l}\text { out } \\
\text { (8) }\end{array}$ & 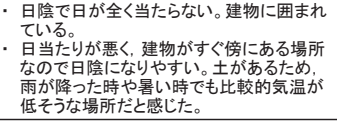 \\
\hline$F$ (8名) & \begin{tabular}{|l} 
out \\
(3)
\end{tabular} & 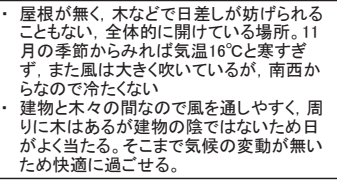 & $\begin{array}{l}\text { out } \\
\text { (9) }\end{array}$ & 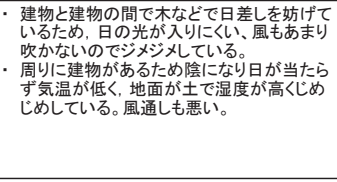 \\
\hline G (6名) & $\begin{array}{l}\text { out } \\
\text { (1) }\end{array}$ & 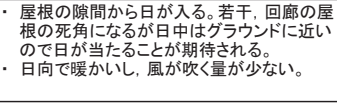 & \begin{tabular}{|l|} 
out \\
110
\end{tabular} & 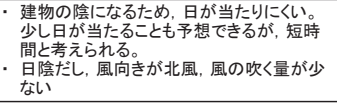 \\
\hline H (6名) & \begin{tabular}{|l} 
out \\
(3)
\end{tabular} & 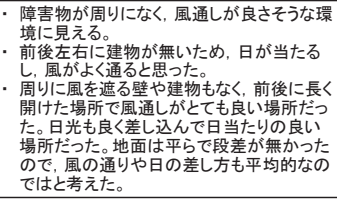 & \begin{tabular}{|l} 
out \\
(11)
\end{tabular} & 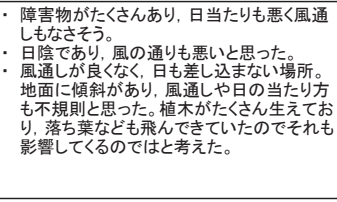 \\
\hline I (6名) & \begin{tabular}{|l} 
out \\
(2)
\end{tabular} & 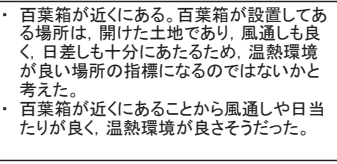 & \begin{tabular}{|l} 
out \\
(5)
\end{tabular} & 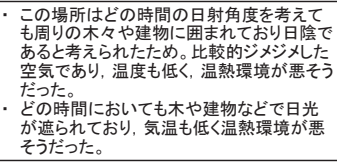 \\
\hline $\mathrm{J}(5$ 名) & \begin{tabular}{|l} 
out \\
(4)
\end{tabular} & $\begin{array}{l}\text { ・タカ像以外は特に日光を遮るものがな } \\
\text { かったため。 } \\
\text { 太陽の光が当たって，風もよく通る。 }\end{array}$ & \begin{tabular}{|l} 
out \\
(12)
\end{tabular} & 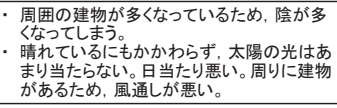 \\
\hline K (5名 & $\begin{array}{l}\text { out } \\
\text { (1) }\end{array}$ & 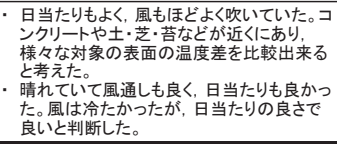 & \begin{tabular}{|l|} 
out \\
110
\end{tabular} & 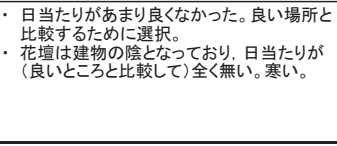 \\
\hline
\end{tabular}

(b) 屋内の実測地点

\begin{tabular}{|c|c|c|c|c|}
\hline \multirow{2}{*}{ (班名 } & \multicolumn{2}{|r|}{ 良いと思った場所 } & \multicolumn{2}{|r|}{ 悪いと思った場所 } \\
\hline & 地点 & 選定理由 & 地点 & 選定理由 \\
\hline A (7名) & & 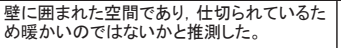 & in (10) & $\begin{array}{l}\text { いつも空気が冷たくかんじていたため観測地 } \\
\text { 点に選んた。 }\end{array}$ \\
\hline B (7名) & in (2) & $\begin{array}{l}\text { 近くの窓から多くの光が入って明るかった。ト } \\
\text { イレの照明の光によって明るかった。 }\end{array}$ & in (9) & $\begin{array}{l}\text { 光があまり入らず日陰だったから。悹の近く } \\
\text { は泠気が漂っていて温度が低かった。 }\end{array}$ \\
\hline C (7名) & in (3) & 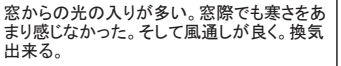 & in (11) & $\begin{array}{l}\text { 光の入りが悪く暗い。風通しが良すぎるた } \\
\text { め, 足下から寒さを感した。 }\end{array}$ \\
\hline D (7名) & in (4) & 最上階なこともあり，日光も良く入る。 & in (12) & $\begin{array}{l}\text { 周りに高い建物(人間関係学部棟) がある } \\
\text { ため光が余り入らず, 階の自動ア゙に-近 } \\
\text { い場所なので。 }\end{array}$ \\
\hline E (7名) & in (5) & $\begin{array}{l}\text { 日当たりが良く,ガラスで园まれていて, 天井 } \\
\text { が高くけた空間で, 床がラローリングのた } \\
\text { め。 }\end{array}$ & in (10) & 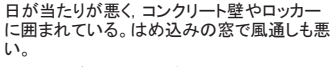 \\
\hline F (8名) & in (6) & $\begin{array}{l}\text { この日は特に天気も良かった。窓際は日の } \\
\text { 光が指して心地良い。 }\end{array}$ & in (11) & 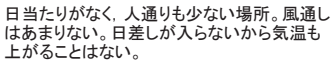 \\
\hline G (6名) & in (7) & 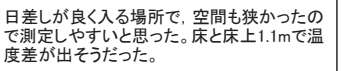 & in (13) & 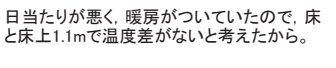 \\
\hline H (6名) & in 8 & $\begin{array}{l}\text { 光が良く当たっていて } \\
\text { たっていて温度が変わ }\end{array}$ & in (14) & $\begin{array}{l}\text { 光りがあたっていなくて暗い印象 } \\
\text { らっ。 }\end{array}$ \\
\hline I (6名) & in (9) & 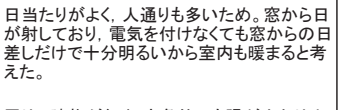 & in (12) & 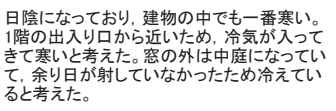 \\
\hline J (5名) & in (6) & $\begin{array}{l}\text { 周りに建物が無く, 方角的にも陽が当たりや } \\
\text { すく崚かいから。 }\end{array}$ & in (10) & $\begin{array}{l}\text { ちょうど陽が当たらず日陰になっっているため, } \\
\text { 温熱環境的に悪そうである。 }\end{array}$ \\
\hline K (5名) & in (10) & 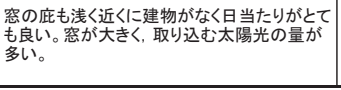 & in (15) & 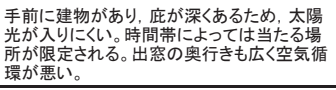 \\
\hline
\end{tabular}


る環境要素への気づきを段階的に検討する．レポート内で提案され た対策は, どの環境要素を問題と認識して対策を提案しているのか, に着目し評価する，レポート内容の検討は，全回答をアフターコー ディングした上で環境要素に関する記述を抽出することで行う.

\subsection{1 対象地の選定理由にみる学生による環境の判断基準}

Table8 に, レポートに記述された屋外及び屋内の実測地点の選定 理由を班ごとに示す，表内の文章は原文ママである．

温熱環境が良いと思った場所の選定理由として, 全ての班が屋外 屋内ともに日射があるか否かで判断している.また 11 班中 5 班が風 速の有無も良好な空間の選定理由として挙げている．屋内の場合， 同一地点であっても測定時刻により日射がある場合は良い，日射が ない場合は悪い温熱環境と判断している。つまり学生の多くは温熱 環境の良し悪しを日射の有無から判断していることが分かる.

\section{4.2 対象地の環境の問題点・対策にみる環境要素への気づき}

続いて, レポートで示された対象地の環境の問題点とその改善策 より，学生が生活空間の環境要素にどの程度気づいたか検討する.

Fig. 10 に一例を, Table9 に改善策の提案にあたり学生が判断した対 象地の環境の問題点の一覧を, Table10 に提案された改善策の一覽 を，それぞれ示す。

結果, 52 名 (75\%)の学生が日照・日射を問題としており (Table9), 導入された改善策 (Table10) は, 緑を中心とした提案が 27 名 (39\%)， 緑と建物の複合案が 24 名 $(35 \%)$ と, 全体の 7 割強の学生が紫外放 射環境の改善に効果的な緑を用いた対策を提案していた。したがっ て節 4.3 .3 において言及した通り，紫外放射環境への意識が確認さ れるとともに, 直前に実施した紫外放射環境に関する講義と演習が, レポート内容に影響した可能性が考えられる。一方，屋外実測時に は全学生が日射のみを対象地の問題点に挙げてしていたが，新たに 季節や時間を問題点や対策に挙げた学生がそれぞれ 35 名 (24\%), 11 名 $(16 \%)$ 存在した。

しかしながら，温熱環境の簡易実測において構成材料の違いに伴 う表面温度の違い等を検討したにもかかわらず，問題点として構成 材料を挙げた学生は 13 名（19\%）と少なく（Table9），提案にまで 繋げた学生は更に少なく 11 名 (16\%) であった（Table10）。

この問題に関しては，レポート作成時に以前行った温熱環境の分析 結果を積極的に参照させるための工夫，及び改善策を提案する前に 対象地の環境に関する知識を総合化する授業回を設ける必要性が確 認された。

\section{4.3 最終レポートでの提案にみる環境への意識の変化}

Table11 に最終レポートにおける対象地の問題点の一覧を, Table12 にその問題点を解決するために導入した対策の一覧を示す. まず授業開始当初は全学生が問題点として選んでいた日当たりや 紫外放射環境を選定した学生は 30 名 (52\%) に減少していた。一方, 建物の配置・空間形態・材料および緑に着目した学生が，それぞれ 12 名 $(21 \%)$ と 6 名 $(11 \%)$ おり，大きな変化といえる（Table11）.

導入された対策をみると, 24 名 (42\%) の学生が緑による対策を, 建物と緑の複合案を合わせると 37 名 $(64 \%)$ の学生が環境の改善策 として緑を導入している（Table12）。しかし，中には土壤が無い状 態で樹木を導入している例や，十分な日射量の得られない北側壁面 に壁面緑化を適用している例など, 緑を手軽な環境改善のアイテム として捉え, 土袞や給水など導入に伴い必要とされるものへの言及

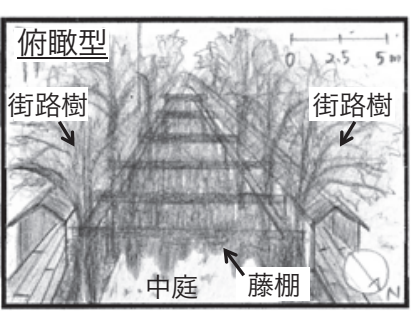

(a) 提案 1 (中庭に藤棚を設置)

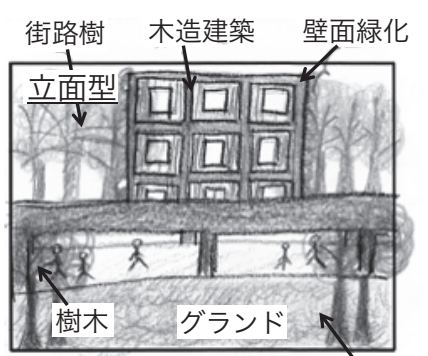

(b) 提案 2 (周囲を緑化) 芝生
Fig.10 Improvement plans proposed by students (example)

Table9 Reasons for selecting the type of counter measures

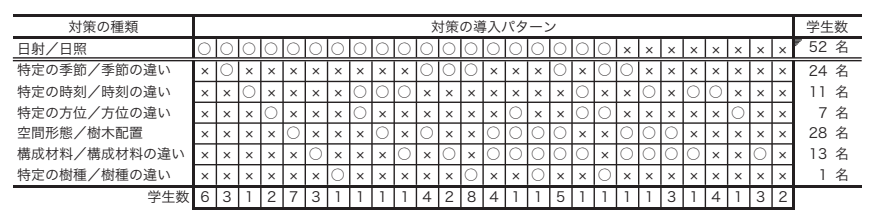

Table10 Improvement plans of all students in the $3^{\text {rd }}$ report

\begin{tabular}{|c|c|c|c|}
\hline 対策の傾向（人数） & \multicolumn{2}{|c|}{ 主な対策手法 } & 付加された対策（人数） \\
\hline \multirow{6}{*}{$\begin{array}{l}\text { 緑中心の対策 } \\
\text { (27) }\end{array}$} & \multirow{2}{*}{\multicolumn{2}{|c|}{ 樹木 }} & 樹木のみ(1 1) \\
\hline & & & $\begin{array}{l}\text { +芝生(5), +空間形態の一部変更(2) } \\
+ \text { +芝生+空間形態の一部変更(1) }\end{array}$ \\
\hline & \multirow{2}{*}{\multicolumn{2}{|c|}{ 植物のアーチ }} & +樹木+芝生(1) \\
\hline & & 緑のカーテン & +追加なし(1)，＋樹木(2)，+芝生(1)，＋壁面緑化(1) \\
\hline & \multirow{2}{*}{\multicolumn{2}{|c|}{ 屋上緑化 }} & +緑のカーテン(1) \\
\hline & & & +緑のカーテン+樹木+芝生+建物配置の変更(1) \\
\hline \multirow{5}{*}{$\begin{array}{c}\text { 緑と建物の複合案 } \\
(24)\end{array}$} & \multirow{5}{*}{\begin{tabular}{|l} 
空間形態と \\
構成材料の \\
変更
\end{tabular}} & +樹木增やす & +芝生(6) \\
\hline & & & 十壁面緑化(3)，十壁面緑化+芝生(2) \\
\hline & & & +屋上緑化(1)，＋屋上緑化+芝生(1) \\
\hline & & 十樹木なくす & 、樹木なくすのみ(9) \\
\hline & & & ＋壁面緑化(1)，＋屋上緑化+壁面緑化(1) \\
\hline \multirow{2}{*}{$\begin{array}{c}\text { 建物中心の対策 } \\
\text { (11) }\end{array}$} & \multirow{2}{*}{\multicolumn{2}{|c|}{ 空間形態と構成材料の変更 }} & I空間形態と構成材料の変更のみ(8) \\
\hline & & & $\begin{array}{l}\text { +壁面緑化(1), } \\
\text { +UV樹木なくす }\end{array}$ \\
\hline \multirow{2}{*}{$\begin{array}{l}\text { 噴水の導入 } \\
\text { (5) }\end{array}$} & \multirow{2}{*}{ 噴水 } & +変更なし & + 樹木(2), +芝生+樹木(1) \\
\hline & & $\begin{array}{l}+ \text { +空間形態と構 } \\
\text { 成材料の変更 }\end{array}$ & +樹木(1), +樹木+屋上緑化(1) \\
\hline 提案なし(2) & & & \\
\hline
\end{tabular}

Table11 Selected problems around students resident in the final report

\begin{tabular}{|c|c|}
\hline 問題点 & 学生数 \\
\hline $\begin{array}{l}\text { 日当たり・日差し／紫外放射環境 } \\
\text { 建物（配置·形態・材料） } \\
\text { 緑（量・種類 } \cdot \text { 配置） }\end{array}$ & $\begin{array}{r}30 \text { 名 } \\
12 \text { 名 } \\
6 \text { 名 }\end{array}$ \\
\hline $\begin{array}{l}\text { 暑さ・寒さ／温冷感 } \\
\text { 通風／風通し } \\
\text { その他（河川, 坂道, ゴミ焼却 } \\
\quad \text { 場, 交通量) }\end{array}$ & $\begin{array}{l}\text { 3名 } \\
\text { 1名 } \\
\text { 2名 }\end{array}$ \\
\hline
\end{tabular}

Table12 Type of counter measures introduced in the final report

\begin{tabular}{|c|c|c|}
\hline \multicolumn{2}{|c|}{ 導入した対策 } & 学生数 \\
\hline 緑による対策 & 樹木 & 13名 \\
\hline & $\begin{array}{l}\text { : 緑のカーテン, } \\
\text { 壁面緑化 }\end{array}$ & 4名 \\
\hline & : 屋上緑化, 複合 & 7名 \\
\hline 緑と建物の複 & & 13名 \\
\hline 建物のみの対 & & 11名 \\
\hline 緑をなくす & & 5名 \\
\hline その他（地形 & 修正） & 3名 \\
\hline 提案なし & & 2名 \\
\hline
\end{tabular}

が疎かになっている提案が少なくない. したがって, 緑などの環境 改善策の導入によるメリットと同時に，デメリット等への言及も必 要であることが明らかとなった.

なお建物のみへの対策を提案した学生が 11 名（19\%), 緑を取り 除く提案をした学生が 5 名 (8\%) おり, 緑の導入に偏重しない学生 も一定数存在していた.

\section{5. まとめ}

本研究は, 建築系複合領域分野の学生を対象に, 生活空間の環境 要素を定量的に把握させ，環境要素ごとに環境と因果関係を理解さ せる建築環境設計の授業プログラムの開発を目指し，第一段階とし 
て, まずは生活空間の環境要素に気づかせることを目的に, 生活空 間の環境要素の簡易実測と紫外放射環境の演習を導入した初学者用 の授業プログラムを開発した。そして環境要素に関する予備知識の 差を考慮するため, 女子大学の学生を対象にプログラムを実践した。 具体的には，以下の知見が得られた。

1）授業内の指示通りに各実測地点の環境要素を測定したレポート 結果より, 本授業プログラムを通して建築系複合領域の初学者が 環境要素を把握できることが確認された.しかしながら誤った測 定結果をそのまま信じているなど測定後の知識の確認作業が必要 であり，授業プログラム構成を一部修正する必要性が明らかとな った.また方位やスケールの明示など, 建築学領域の学生とは異な ると考えられる対応の必要性も示唆された.

2）実測・演習のレポートの感想より, 簡易な実測機器であっても学 生自身に作成・測定させることで, 建築系複合領域分野の初学者 にも授業に興味を持たせることが可能であることが確認された.

3）また確認シートによる環境要素の理解度の確認より, 紫外放射環 境に関して日常的に紫外放射環境を意識している女子大学の学生 特有と考えられる反応がみられ，環境要素の気づきへの日常的な 啓発の重要性も示唆された.

4）更にレポートと最終レポートにおける屋外及び屋内の実測地点 の選定理由とそこへの改善策の提案より，当初は日当たりのみに 着目していた学生が他の環境要素についても言及するようになっ たことから，学生に環境要素に気づかせるという本授業プログラ ムの目標は達成できたと考える.

5）しかしながら対象地の環境の改善策は紫外放射環境の改善に偏 った提案が中心となっており，温熱環境・紫外放射環境の両方を 考察させるには授業プログラムの一部を修正する必要がある。

一方，レポート内の文章において一部の学生が周囲の生活空間の 環境を捉える際，空気の温度である気温と固体表面の温度である表 面温度とを区別できず，全て「温度」と表現するなど，環境要素に 正しく気づけていない可能性がみてとれた．建築系複合領域分野の 学生への教育を進めていく上で,この様な事例の把握は重要であり, 今後取り組むべき課題と考える。

\section{謝辞}

本研究を行うにあたり, 授業に参加してくださった学生の皆様に ご協力いただきました。ここに記して感謝いたします.

本研究は，科学研究費補助金（基盤研究 (C)一般)，3 D C A D 対 応数值シミュレーションを取り入れた建築環境設計の授業プログラ ムの開発（課題番号：24560711，代表：梅干野昆）の一環として行 われたものである。

\section{注}

注 1）本数値は下記資料に掲載されている国内の全大学について，各大学の カリキュラムを別途公式ホームページで調査して導出した．各分野の選定 条件は, カリキュラムに建築・住宅のデザイン作業があることを共通項に, 取得可能資格が一級建築士である学科・専攻を建築学分野，建築学分野以 外の他分野の科目がカリキュラムにあり，かつ取得可能資格が二級建築士 である学科・専攻を建築系複合領域分野とした. 同一大学で建築学分野の学 科が複数存在する場合は両方を計上した。（出典：蛍雪時代編集部：2017 (平成 29）年度用 大学の真の実力 情報公開 B00K, 旺文社, 2016.9)

注 2) 本研究で使用した放射温度計のメーカーカタログでの測定精度は， 士 $2 \%$ または土 $2^{\circ} \mathrm{C}$ (数值の大きい方) である。実測時の外気温は $16.5^{\circ} \mathrm{C}(11$
月 11 日）, $13.5^{\circ} \mathrm{C}$ （12 月 2 日）であり，実測地点周辺の表面温度も当時 の外気温相当であったため, 測定精度は $\pm 2{ }^{\circ} \mathrm{C}$ なる.

\section{本論文に関連する既発表文献}

*1）谷口新, 高田眞人, 小高典子, 梅干野昆: 実測演習を導入した建築環境 設計の授業プログラムの開発と試行 その 1 屋外温熱環境の簡易実測, 日本建築学会大会学術講演梗概集（関東），pp. 5-6, 2015.9

*2）高田眞人, 谷口新, 小高典子, 梅干野晁：実測演習を導入した建築環境 設計の授業プログラムの開発と試行 その 2 屋外紫外放射環境の評価と 改善策の提案，日本建築学会大会学術講演梗概集（関東），pp. 7-8，2015.9

\section{参考文献}

1）梅干野沓, 浅輪貴史, 中大窪千晶：3D-CAD と屋外熱収支数值シミュレー ションを一体化した環境設計ツール, 日本建築学会技術報告集, 第 20 号, pp. 195-198, 2004. 12

2）中大窪千晶, 梅干野晁, 円井基史：熱環境設計教育の基本的考えと授業 プログラムの提案 - $3 \mathrm{D}-\mathrm{CAD}$ 対応熱環境シミュレータを用いた建築環境設計 教育その 1 -, 平成 22 年度工学・工業教育研究講演会講演論文集, pp. 366-367, 2010.8

3）円井基史, 梅干野沓, 中大窪千晶：建築系学部 3 年生を対象とした熱環 境設計授業の実践 $-3 \mathrm{D}-\mathrm{CAD}$ 対応熱環境シミュレータを用いた建築環境設計 教育その 2-, 平成 22 年度工学・工業教育研究講演会講演論文集, pp. 368-369, 2010.8

4）高田眞人, 河合英徳, 梅干野冢：建築環境設計のプロセスの習得を目的 とした授業プログラムの開発, その 1 数值シミュレーションを導入した 建築環境設計の授業の試行, 2011 年度日本建築学会関東支部研究報告集, pp. 97-100, 2012.3

5）河合英徳，高田眞人，梅干野昆：建築環境設計のプロセスの習得を目的 とした授業プログラムの開発，その 2 数值シミュレーションの建築環境 設計のための授業への導入における課題の抽出, 2011 年度日本建築学会関 東支部研究報告集，pp. 101-104，2012.3

6) 大西康伸, 両角光男：3DCAD 及び解析ソフトを活用した包括的建築教育プ ログラムの開発とその評価，日本建築学会計画系論文集，Vol. 76, pp. 1337-1345, No. 665 , 2011. 11

7）澤田英行, 佐藤康平, 豊田郁美, 根本雅章：BIM・ICT を活用したアクテ イブ・ラーニングの実践, e-Learning システム「Web Learning Studio」 による建築設計教育の試み その 3 , 建築教育研究論文報告集, No. 14 , pp. 11-18, 2014. 11

8）田中稲子, 村上美奈子, 谷口新, 望月悦子, 古賀誉章, 高口洋人：杉並 区エコスクールにおける住環境学習プログラムの開発, 荻窪小学校におけ る萌芽段階の事例評価, 日本建築学会技術報告集, 第 17 巻, 第 36 号, pp. $755^{-758,2011.6}$

9）川北健雄, 花田佳明, 三上晴久, 倉知徹, 水島あか衩：ステップ・バイ・ ステップ方式を用いた初学者向け建築設計教育プログラムの実践と教科書 の出版， 2011 年日本建築学会教育賞 (教育貢献), (http://www. aij.or. jp/jpn/design/2011/prize2011.htm:2016/9/9 現在)

10）川北健雄, 花田佳明, 三上晴久, 倉知徹, 水島あか放：初めての建築設 計ステップ・バイ・ステップ，彰国社，2010.4

11）小泉武栄，原芳生：身近な環境を調べる, 古今書院，2002.7

12）川西利昌：紫外線・熱中症を防ぐ日除け，技報堂出版株式会社，2012.7 
INSTALLATION EFFECT OF FIELD MEASUREMENT AND PRACTICAL EXERCISE ON ENVIRONMENTAL ELEMENTS UPON ARCHITECTURAL BEGINNERS IN COMPOSITE REGION

Development and practice of educational program for architectural environmental design: Part 1

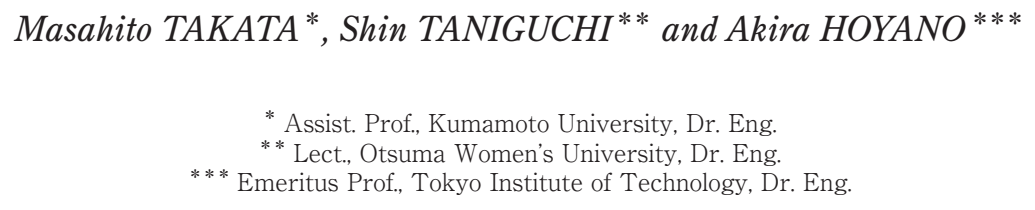

For enhancing the general level of understanding toward architectural environmental design, it is important not only for ordinal architectural students but also for architectural students in composite regions to imagine environmental elements in their design. As a first step, discovery of environmental elements in living areas was important for the introduction of understanding the relation between architectural design and environment. On the other hand, the number of composite regions in architecture becomes too large to ignore. It is worth enough to develop the educational program for architectural students in this field.

In this study, as a means of addressing this issue, educational program, in which simple field measurement on thermal environment and practical exercise on ultraviolet environment was introduce for the discovery of environmental elements in living areas, had been developed and conducted for architectural beginners in composite regions.

Based on the previous studies about architectural educational programs for undergraduate students, the educational program in this study is divided into some stages. In each stage, challenges and work descriptions are set to meet the minimal performance standard for the purpose of understanding and acquiring the image of environmental elements in living areas. In this program, the environmental elements comprises of three topics, outdoor thermal environment, indoor thermal environment, and ultraviolet radiation environment. Simple field measurements and practical exercises are introduced, for the purpose of discovering the image of environment elements in living areas directly by students. Each topic consists of three steps: 1) lecture, 2) simple field measurement / practical exercise, 3) report. Finally, countermeasures of the target site are proposed in a final paper by students to finish up this program. Field measurement is for thermal environment, and practical exercise is for ultraviolet radiation environment.

The program was developed and conducted for 4 months (Sep.-Dec.2013.) as part of usual didactic course, offered to third grade undergraduate students, most of them were architectural beginners, at composite regions in architecture, Otsuma Women's University, Japan. The following 6 environmental elements are treated and measured by the students; air temperature, relative humidity, wind direction, wind velocity, surface temperature, and ultraviolet radiation environment.

The results confirmed that the program successfully ensured students' measurement on environmental elements in living areas, even if both the students were architectural beginners in composite regions and the contents of the program, field measurement and practical exercise, were too simple in total. The high percentage of correct answer on ultraviolet radiation environment in the before-and-after quiz also showed the possibility of students' interest enhancing the discovery on environmental elements, because all the students were women. Moreover, from the increase in number of the students' description about environmental elements in the reports and the final paper, the educational program enhanced students' discovery on environmental elements.

On the other hand, some areas were highlighted for improvement with regards to the content of the lectures and reports in the program, especially on students' misunderstanding and miscalculation on environmental elements. This showed the needs of improvement in the next paper. 